\title{
Mini Review \\ Advantages of Herbal Over Allopathic Medicine in the Management of Kidney and Urinary Stones Disease
}

\author{
Saurabh Nimesh ${ }^{1^{*}(c)}$ \\ Vrish Dhwaj Ashwlayan 20 \\ Rubi Rani 3 \\ Om Prakash 1 \\ 1Department of Pharmacology, Shri \\ Gopichand College of Pharmacy, \\ Baghpat, Uttar Pradesh, India \\ 2Department of Pharmaceutical \\ Technology, Meerut Institute of \\ Engineering and Technology, Meerut, \\ Uttar Pradesh, India \\ ${ }^{3}$ Department of Pharmaceutical \\ Technology, NKBR College of \\ Pharmacy and Research Centre, Meerut, \\ Uttar Pradesh, India \\ *email: nimeshmiet@gmail.com \\ Keywords: \\ Allopurinol \\ Ayurveda \\ Hyperoxaluria \\ Uric acid \\ Xanthium strumarium
}

\begin{abstract}
Kidney and urinary stone disease (Nephrolithiasis and urolithiasis) are the condition where urinary stones or calculi are formed in the urinary tract. The problem of urinary stones is very ancient; these stones are found in all parts of the urinary tract, kidney, ureters, and the urinary bladder and may vary considerably in size. It is a common disease estimated to occur in approximately $12 \%$ of the population, with a recurrence rate of $70-81 \%$ in males and $47-60 \%$ in females. The treatment of kidney and urinary stone diseases such as a western (allopathy) medicine and surgery is now in trends. However, most people preferred plant-based (herbal) therapy because of the overuse of allopathic drugs, which results in a higher incidence rate of adverse or severe side effects. Therefore, people every year turn to herbal therapy because they believe plant-based medicine is free from undesirable side effects, although herbal medicines are generally considered to be safe and effective. In the present article, an attempt has been made to emphasize an herbal therapy is better than allopathic therapy for the management of the kidney and urinary stone disease.
\end{abstract}

Received: May 27th, 2020

Accepted: July 26th, 2020

Published: August 31st, 2020

(C) 2020 Saurabh Nimesh, Vrish Dhwaj Ashwlayan, Rubi Rani, Om Prakash. Published by Institute for Research and Community Services Universitas Muhammadiyah Palangkaraya. This is an Open Access article under the CC-BY-SA License (http://creativecommons.org/licenses/by-sa/4.0/) DOI: https:// doi.org/10.33084/bjop.v3i3.1415

\section{INTRODUCTION}

The urinary framework is comprised of two significant bean-molded kidneys, ureters, bladder, and urethra. These bean-formed kidneys are found only at the center of the back and beneath the sets of ribs. The kidney transports water and squanders from the flowing blood and converts it to form urine (Aune et al., 2018). These are likewise helpful for making an equilibrium balance of salts and different ions in the blood. The tubes of the urethras, which are restricted in size, convey urine creation from the kidneys, which transport it to a triangle- shaped chamber called the bladder (Fisang et al., 2015). Simultaneously, urine is put away in a versatile inflatable sort chamber called bladder, which gets straightened when urine is expelled through the urethra out the body. The term 'Urolithiasis' is a worldwide issue influencing human beings, called 'Nephrolithiasis' or kidney stones. Urolithiasis is a condition in which the crystals of uroliths/stones present in the urinary tract are summarized in Figure 1 (Abdel-Daim et al., 2017). In the Conventional world, the yearly frequency of urolithiasis has been about $0.5 \%$ with a lifetime risk of creating is about $10-15 \%$, yet its increment with $20-25 \%$ in the 
Middle East. Urolithiasis is the arrangement of uneven calculi or the condition which has a place with urinary calculi (Ahmed et al., 2015). The condition of calculi is synonymous with the term uroliths, stones, or crystals. These calculi are made of polycrystalline totals made out of the crystalloid and organic matrix (Han et al., 2015). These calculi can fit as a fiddle and find any place in the urinary tract from the kidney to the bladder (Arya et al., 2017).

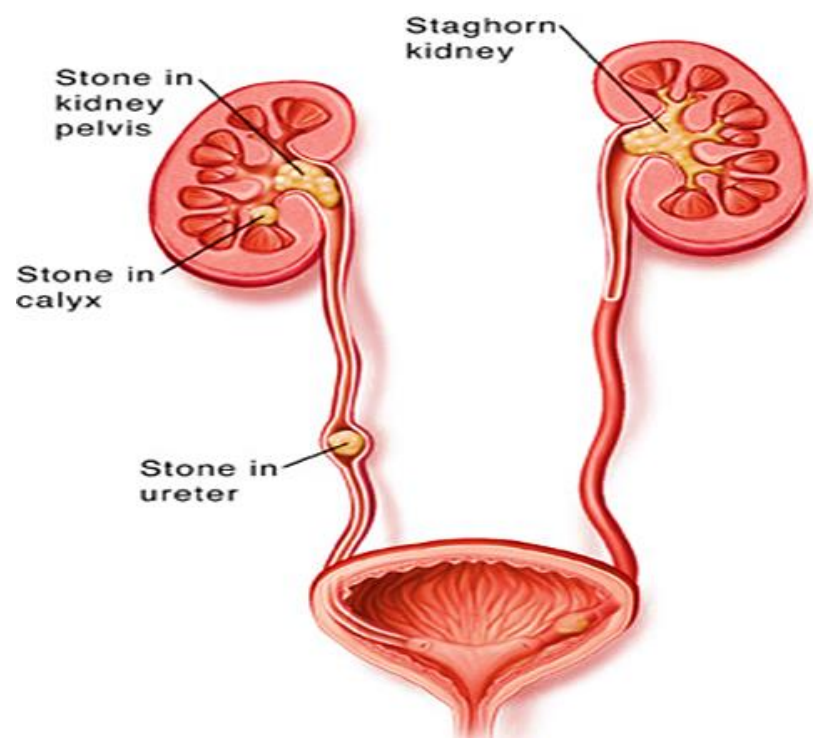

Figure 1. Locations of kidney and urinary stones in the urinary tract (Rodgers et al., 2016).

A kidney stone is a group of crystals formed together to make a hard lump in both kidneys. They can shift in size from a few millimeters to several centimeters. Most of the stones will drop off the urine body, with no assistance, yet some will require intervention to expel them (Jung \& Osther, 2015). The urinary stones have been created with the crystals of phosphate, uric acid, magnesium ammonium phosphate with apatite, and struvite. Among the urinary stones, calcium-containing stones have been found about $75 \%$ of every single urinary calculi, which might be available as crystals of unadulterated Calcium oxalate $\left(\mathrm{CaC}_{2} \mathrm{O}_{4}\right) 50 \%$, calcium phosphate $5 \%$, and a mixture of both compounds $45 \%$ (Ferraro et al., 2017). The diet can influence the concentration of specific substances in the urine and influence urine acidity. The 24 hours assortment of urine may find any given properties have expanded the risk of forming stones enlisted in Table I (Aziz \& Hassan, 2020). Calcium oxalate, uric acid, and citrate are typical substances found in the blood (Khan, 2016). The acidity of any liquid is expressed as $\mathrm{pH}$. The $\mathrm{pH}$ of $<7$ is acidic, while $\mathrm{pH}>7$ is alkaline (Coe et al., 2016). The normal urine $\mathrm{pH}$ will change during the day, rely upon diet, and usually range between 5 and 8 . Calcium oxalate stones can befound in any $\mathrm{pH}$ of urine. The development of uric acid stones is more in acidic urine, while calcium phosphate forms in more alkaline urine (Cakıroğlu et al., 2016).

Table I. Salt composition of the kidney (Chen et al., 2018)

\begin{tabular}{ll}
\hline \multicolumn{1}{c}{ Term } & \multicolumn{1}{c}{ Descriptions } \\
\hline Hypocitraturia & Low levels of citrate \\
Hypercalciuria & High levels of calcium \\
Hyperuricemia & High levels of uric acid \\
Hyperoxaluria & High levels of oxalate \\
\hline
\end{tabular}

The chemical composition of kidney stones depends on the abnormalities in the urine composition of various chemicals. Human kidney stones are commonly classified into five types, as follows in Table II (Albert et al., 2017).

Table II. Five types of kidney and urinary stones and their descriptions (Kummer et al., 2015)

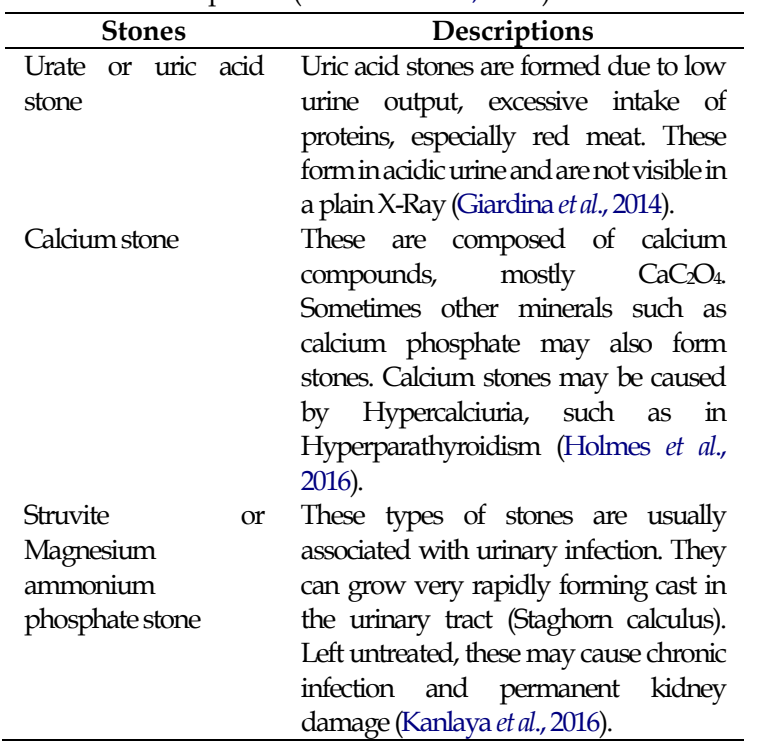




\begin{tabular}{ll}
\hline Cystine stone & $\begin{array}{l}\text { These occur due to an inherited defect in } \\
\text { amino acid transport, manifests as } \\
\text { recurrent stones in young patients }\end{array}$ \\
Drug-Induced stone & $\begin{array}{l}\text { This accounts for about } 1 \% \text { of all stone } \\
\text { types. Drugs such as guaifenesin, } \\
\text { triamterene, atazanavir, and sulphas } \\
\text { drugs induce these stones (Bultitude et } \\
\text { al.,2016). }\end{array}$ \\
\hline
\end{tabular}

In this mini-review, we will discuss the various advantages of herbal medicines, especially those used in ayurvedic therapy, compared to the use of various allopathic drugs to manage kidney and urinary stones disease. The advantages discussed are mainly from the side effects that occur from the use of these drugs. In addition, several things related to kidney and urinary stones disease will also be discussed, including epidemiology, pathophysiology, symptoms, diagnosis, and prevention.

\section{EPIDEMIOLOGY}

Globally, kidney and urinary stones disease pervasiveness and repeat rates are expanding, with limited choices of effective drugs (Evan et al., 2015). Urolithiasis influences about $12 \%$ of the total population at some phase in their lifetime. It influences all ages, genders, and races. However, it happens more now and again than in women aged 20-49 years (Chauveau et al., 2018). If patients do not make a difference metaphylaxis, the backsliding pace of secondary stone developments is assessed to be $10-23 \%$ every year, $50 \%$ in 5-10 years, and $75 \%$ in 20 years (Green \& Ratan, 2013). In any case, the lifetime repeat rate is higher in males, even though nephrolithiasis is developing among females. Subsequently, prophylactic management is of great importance to manage kidney stones (Daudon et al., 2018). Ongoing investigations have revealed that urolithiasis' predominance has been expanding in the previous decades in both developed and developing countries (Duan et al., 2020). This development pattern is accepted to be related to changes in the way of lifestyle modifications, for example, the absence of physical action and dietary propensities and global warming. In the United States, kidney stones influence 1 of every 11 individuals, and it is assessed that 600,000 Americans experience the ill effects of urinary stones each year. In the Indian population, about $12 \%$ of them are relied upon to have urinary stones, and out of which, 50\% may end up with the loss of kidney capacities (Cloutier et al., 2015).

\section{PATHOPHYSIOLOGY}

The pathophysiology of kidney stones is not yet fully understood. Despite increasing study in the last decade, the mechanisms whereby $\mathrm{CaC}_{2} \mathrm{O}_{4}$ crystals are retained in the kidney and form renal stones remain (Gambaro et al., 2017). The formation of stone required supersaturated ionic urine, summarized in Figure 2. The level of supersaturation is also dependent on urinary $\mathrm{pH}$, ionic strength, solute concentration in the urine, and complications (Gambaro et al., 2016). Three conditions must coexist for the formation of struvite calculi:

1. An alkaline $\mathrm{pH}$ of urine

2. The presence of urea or ammonia in the urine

3. A high amount of minerals in the urine.

Urinary saturation

Crystallization nucleation, growth, \& aggregation Renal tubular injury Crystal- cell interaction

Crystal growth, crystal aggregation

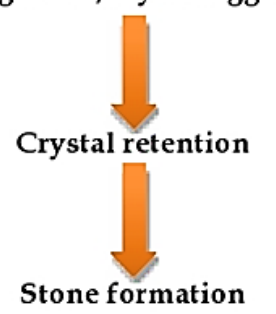

Figure 2. The formation process of stones in kidney and urinary tract (Ferraro et al., 2019). 


\section{SYMPTOMS}

Stones in the kidney frequently do not cause any signs and symptoms and can go undiagnosed. At the point when a stone leaves the kidney, it goes to the bladder through the ureter. Regularly the stone can become stopped in the ureter (Khan et al., 2016). When the stone obstructs urine progression out of the kidney, it can make the kidney swell (hydronephrosis), regularly causing much pain. Common symptoms of kidney stones are:

1. Sharp, squeezing torment in the back and side, regularly moving to the lower abdomen or groin (Smith-Bindman et al., 2014). Some female says the pain is worse than childbirth labor pains. The pain frequently begins all of a sudden and comes in waves. It can come and go as the body tries to get rid of the stone (Afsar et al., 2016)

2. A feeling of intense need to urinate

3. Urinating more often or a burning feeling during urination

4. Urine is dark or red due to blood. Sometimes urine has only small amounts of red blood cells that cannot be seen with the naked eye (Hollingsworth et al., 2016)

5. Men may feel pain at the tip of their penis (Das \& Malipeddi, 2016).

\section{DIAGNOSIS}

Diagnosis of kidney and urinary stones requires a complete health history assessment, laboratory or imaging tests, and a physical exam. Other tests include in

Table III (Courbebaisse et al., 2017).

Table III. Nephrologist uses diagnostic tests of kidney and urinary stones and their descriptions

\begin{tabular}{cl}
\hline Tests & \multicolumn{1}{c}{ Descriptions } \\
\hline Blood testing & $\begin{array}{l}\text { Blood tests measure too much calcium or uric } \\
\text { acid in the blood. Blood test results help } \\
\text { monitor the kidney's health and may lead the } \\
\text { nephrologist to check for other medical } \\
\text { conditions (Zhu et al., 2014). }\end{array}$ \\
Urine testing & $\begin{array}{l}\text { The 24-hours urine collection test may show } \\
\text { that the kidney is excreting too many stones- } \\
\text { forming minerals or too few stones preventing }\end{array}$ \\
\hline
\end{tabular}

\begin{tabular}{ll}
\hline & $\begin{array}{l}\text { substances. For this test, the nephrologist may } \\
\text { request to perform two urine collections over } \\
\text { two consecutive days (Ragettli et al., 2017). }\end{array}$ \\
Imaging test & $\begin{array}{l}\text { Imaging tests may show the availability of } \\
\text { kidney stones in the urinary tract. Options } \\
\text { range from simple abdominal X-rays, which } \\
\text { can miss small kidney stones, to high-speed or } \\
\text { dual energy computerized tomography (CT) } \\
\text { that capture even tiny stones (Kapoor et al., } \\
\text { 2017). } \\
\text { Other imaging } \\
\text { options }\end{array} \quad \begin{array}{l}\text { An ultrasound, a non-invasive test, and } \\
\text { intravenous urography, which involves } \\
\text { injecting dye into an arm vein and taking X- } \\
\text { rays (intravenous pyelogram) or obtaining CT } \\
\text { images (CT urogram) as the dye travels } \\
\text { through the kidneys and the bladder } \\
\text { (Nirumand etal., 2018). }\end{array}$ \\
\hline
\end{tabular}

\section{TREATMENT}

\section{Herbal medicine}

According to the World health organization estimate, $80 \%$ population living in developing countries almost exclusively uses herbal medicines. This means that 3,330 million people use herbal medicines regularly (Sharifiyan et al., 2016). Ayurveda, an indigenous system of Indian medicine, offers immense extensions of the successful treatment of kidney stones disease described in Table IV (Tavasoli et al., 2020).

Table IV. List of herbal drugs used in the treatment of kidney and urinary stones

\begin{tabular}{|c|c|c|}
\hline $\begin{array}{l}\text { Scientific name } \\
\text { (Family) }\end{array}$ & $\begin{array}{c}\text { Common } \\
\text { name }\end{array}$ & Mode of intake and use \\
\hline Zea mays (Poaceae) & $\begin{array}{l}\text { Corn, } \\
\text { Makka }\end{array}$ & $\begin{array}{l}\text { The decoction of the female } \\
\text { inflorescence or immature cobs } \\
\text { areorally administered to expel } \\
\text { the kidney stones; Dose: two } \\
\text { times a day for seven days } \\
\text { (Pathan } \text { et al., 2018). }\end{array}$ \\
\hline $\begin{array}{l}\text { Aegle marmelose } \\
\text { (Rutaceae) }\end{array}$ & Bael, Bilwa & $\begin{array}{l}\text { Dried fruit pulp powder is } \\
\text { given orally with coconut milk } \\
\text { to dissolve kidney stones; Dose: } \\
\text { a teaspoon powder with } 100 \mathrm{ml} \\
\text { of coconut milk taken two } \\
\text { times a day for } 14 \text { days (Unno } \\
\text { et al., 2020). }\end{array}$ \\
\hline $\begin{array}{l}\text { Cynodon dactylon } \\
\text { (Poaceae) }\end{array}$ & $\begin{array}{l}\text { Garika } \\
\text { gaddi }\end{array}$ & $\begin{array}{l}\text { The whole plant extract was } \\
\text { given orally to dissolve kidney } \\
\text { stones; Dose: } 10-20 \mathrm{ml} \text { extract } \\
\text { taken two times a day for ten } \\
\text { days. }\end{array}$ \\
\hline $\begin{array}{l}\text { Strychnos } \\
\text { potatorum } \\
\text { (Loganiaceae) }\end{array}$ & $\begin{array}{l}\text { Chilla } \\
\text { ginjalu }\end{array}$ & $\begin{array}{l}\text { The decoction of roots taken } \\
\text { orally to dissolve and expel } \\
\text { kidney stones; Dose: a teacup } \\
\text { decoction taken two times a } \\
\text { day for } 20 \text { days (Yiu et al., 2015). }\end{array}$ \\
\hline $\begin{array}{l}\text { Tribulus terrestis } \\
\text { (Zygophyllaceae) }\end{array}$ & $\begin{array}{l}\text { Gokharu, } \\
\text { Devil's- } \\
\text { thorn }\end{array}$ & $\begin{array}{l}\text { Fruits and root decoction are } \\
\text { given orally to be used to treat } \\
\text { kidney stones; Dose: three }\end{array}$ \\
\hline
\end{tabular}




\begin{tabular}{|c|c|c|}
\hline & & $\begin{array}{l}\text { times a day is taken regularly } \\
\text { for } 14 \text { days. }\end{array}$ \\
\hline $\begin{array}{l}\text { Tinospora cordifolia } \\
\text { (Menispermaceae) }\end{array}$ & $\begin{array}{l}\text { Guduchi, } \\
\text { Giloy }\end{array}$ & $\begin{array}{l}\text { Crushed stem powder is given } \\
\text { orally to expel the kidney } \\
\text { stones; Dose: } 5 \text { g taken daily for } \\
14 \text { days (Spatola } \text { et al., 2018). }\end{array}$ \\
\hline $\begin{array}{l}\text { Celosia argentea } \\
\text { (Amaranthaceae) }\end{array}$ & Gunugu & $\begin{array}{l}\text { Dried seeds powder is orally } \\
\text { administered to dissolve } \\
\text { kidney stones; Dose: } 1 \mathrm{~g} \\
\text { powder taken one time a day } \\
\text { for five days. }\end{array}$ \\
\hline $\begin{array}{l}\text { Phyllanthus } \\
\text { fraternus } \\
\text { (Euphorbiaceae) }\end{array}$ & $\begin{array}{l}\text { Gulf leaf- } \\
\text { flower, Bhoi } \\
\text { amli }\end{array}$ & $\begin{array}{l}\text { Fresh plant extract pounded } \\
\text { with pepper and turmeric } \\
\text { extract is administered orally to } \\
\text { dissolve the stones; Dose: } 2 \mathrm{~g} \\
\text { taken daily for five days (Wang } \\
\text { et al., 2016). }\end{array}$ \\
\hline $\begin{array}{l}\text { Bryophyllum } \\
\text { pinnatum Oken. } \\
\text { (Crassulaceae) }\end{array}$ & $\begin{array}{l}\text { Patharchata, } \\
\text { Ajjuba, } \\
\text { Ghavpatta }\end{array}$ & $\begin{array}{l}\text { Fresh leaf juice and kalimirch } \\
\text { powder are given orally to } \\
\text { dissolve and expel kidney } \\
\text { stones; Dose: Taken two times } \\
\text { a day for } 15 \text { days. }\end{array}$ \\
\hline $\begin{array}{l}\text { Boerhaavia diffusa } \\
\text { (Nyctaginaceae) }\end{array}$ & $\begin{array}{l}\text { Bishkapra, } \\
\text { Punarnava }\end{array}$ & $\begin{array}{l}\text { The root decoction is orally } \\
\text { administered to expel kidney } \\
\text { stones; Dose: Taken daily for a } \\
\text { month (Türk et al., 2016). }\end{array}$ \\
\hline
\end{tabular}

\section{Allopathic medicine}

Patients with kidney and urinary stones, a nephrologist may also prescribe allopathic medicines to prevent future kidney stones (Wijarnpreecha et al., 2018). Depending on the 24-hour urine collection result, there are different treatment options for different kidney stones types (Vicedo-Cabrera et al., 2020). Now there is convincing evidence that by treating specific biochemical abnormalities, the recurrence rate can be reduced. Commonly three classes of allopathic medications used for kidney and urinary stones management are enlisted in Table V (Ross et al., 2018).

Table V. Treatment of kidney and urinary stones with conventional (allopathic) medicines

\begin{tabular}{llll}
\hline \multicolumn{1}{c}{ Classes } & \multicolumn{1}{c}{ Drugs } & \multicolumn{1}{c}{ Uses } & \multicolumn{1}{c}{$\begin{array}{c}\text { Side } \\
\text { effects }\end{array}$} \\
\hline $\begin{array}{l}\text { Sulphonamide } \\
\text { derivatives }\end{array}$ & Zonisamide & $\begin{array}{l}\text { Ailments of } \\
\text { kidney and } \\
\text { urinary stone }\end{array}$ & $\begin{array}{l}\text { Lightheaded- } \\
\text { ness, } \\
\text { shortness of } \\
\text { breath, rapid } \\
\text { heart rate, } \\
\text { trouble } \\
\end{array}$ \\
& & & $\begin{array}{l}\text { concentrating } \\
\text { and fever } \\
\text { (Pozdzik et } \\
\text { al., 2019). } \\
\text { Bisphosphonate }\end{array}$ \\
& Etidronate & & $\begin{array}{l}\text { Stomach } \\
\text { upset or } \\
\text { disodium }\end{array}$ \\
& & Kidney \\
& stones & muscle pain, \\
& & & mood \\
\hline
\end{tabular}

\begin{tabular}{|c|c|c|c|}
\hline & & & $\begin{array}{l}\text { changes, and } \\
\text { allergic } \\
\text { reactions } \\
\text { (rash, } \\
\text { itching). }\end{array}$ \\
\hline $\begin{array}{l}\text { Cardiac } \\
\text { glycoside }\end{array}$ & Digoxin & $\begin{array}{l}\text { Ailments of } \\
\text { kidney and } \\
\text { urinary } \\
\text { stones }\end{array}$ & $\begin{array}{l}\text { Skin rash, } \\
\text { itching, } \\
\text { blurred } \\
\text { vision, } \\
\text { anxiety, } \\
\text { depression, } \\
\text { and severe } \\
\text { stomach pain } \\
\text { (Prabhu et al., } \\
\text { 2016). }\end{array}$ \\
\hline $\begin{array}{l}\text { Bile acid } \\
\text { sequestrates }\end{array}$ & Cholestyramine & $\begin{array}{l}\text { Kidney } \\
\text { diseases }\end{array}$ & $\begin{array}{l}\text { Unusual } \\
\text { bleeding/ } \\
\text { bruising, } \\
\text { rapid } \\
\text { breathing, } \\
\text { confusion, } \\
\text { vomiting, } \\
\text { and loss of } \\
\text { appetite } \\
\text { (Skolarikos et } \\
\text { al., 2015). }\end{array}$ \\
\hline $\begin{array}{l}\text { Analogue of } \\
\text { hypoxanthine }\end{array}$ & Allopurinol & $\begin{array}{l}\text { Treatment of } \\
\text { urinary } \\
\text { infections and } \\
\text { calculi }\end{array}$ & $\begin{array}{l}\text { Persistent } \\
\text { nausea/ } \\
\text { vomiting, } \\
\text { dark urine, } \\
\text { unusual } \\
\text { weight loss, } \\
\text { vision } \\
\text { changes, and } \\
\text { severe } \\
\text { dizziness } \\
\text { (Prezioso et } \\
\text { al.,2016). }\end{array}$ \\
\hline Diuretics & Amiloride & $\begin{array}{l}\text { Treatment of } \\
\text { kidney- } \\
\text { related } \\
\text { problems }\end{array}$ & $\begin{array}{l}\text { Abdominal } \\
\text { pain, } \\
\text { shortness of } \\
\text { breath, } \\
\text { weakness/ } \\
\text { heaviness of } \\
\text { the legs, } \\
\text { vomiting, } \\
\text { and } \\
\text { wheezing } \\
\text { (McTavish et } \\
\text { al.,2018). }\end{array}$ \\
\hline $\begin{array}{l}\text { Nonsteroidal } \\
\text { anti- } \\
\text { inflammatory } \\
\text { drug(NSAIDs) }\end{array}$ & $\begin{array}{l}\text { Ibuprofen, } \\
\text { acetaminophen, } \\
\text { and naproxen }\end{array}$ & $\begin{array}{l}\text { Acute renal } \\
\text { colic and } \\
\text { inhibit pain } \\
\text { and } \\
\text { inflammatory } \\
\text { reactions }\end{array}$ & $\begin{array}{l}\text { Peptic ulcers, } \\
\text { renal failure, } \\
\text { stroke and } \\
\text { heart disease, } \\
\text { allergic } \\
\text { reactions } \\
\text { (itching, rash, } \\
\text { swelling), } \\
\text { sensitivity to } \\
\text { light (Ticinesi } \\
\text { etal., 2018). }\end{array}$ \\
\hline Opioid drugs & $\begin{array}{l}\text { Morphine and } \\
\text { meperidine }\end{array}$ & $\begin{array}{l}\text { Management } \\
\text { of renal colic } \\
\text { pain and } \\
\text { perioperative } \\
\text { pain }\end{array}$ & $\begin{array}{l}\text { Sedation, } \\
\text { dizziness, } \\
\text { nausea and } \\
\text { vomiting, } \\
\text { constipation, } \\
\text { physical } \\
\text { dependence, } \\
\text { tolerance, } \\
\text { and } \\
\text { respiratory } \\
\text { depression } \\
\text { (Primarizky } \\
\text { etal., 2016). }\end{array}$ \\
\hline
\end{tabular}




\section{PREVENTION}

Kidney stones disease is a silent killer. Patients at high risk of stone recurrence should receive preventive measures tailored to the metabolic assessment (Shang et al., 2017). Generally, a simple and most important lifestyle change to prevent stones disease is to drink 4-6 L water/liquids/fluids per day, proper management of diet, and the use of medications is required (Ticinesi et al., 2019). Enough liquid intake reduces urinary saturation and dilutes promoters of $\mathrm{CaC}_{2} \mathrm{O}_{4}$ crystallization. Thus, nutritional management is the best preventive strategy against Urolithiasis (Streeper, 2018). The five practical steps to prevent kidney stones disease described in Table

VI.

Table VI. The five ways adopt in daily routine described may help to keep the kidney stones disease (Rodger et al., 2018)

\begin{tabular}{|c|c|}
\hline Steps & Descriptions \\
\hline $\begin{array}{l}\text { Healthy and } \\
\text { balanced diet }\end{array}$ & $\begin{array}{l}\text { Eat healthy food, plenty of fresh fruits and } \\
\text { vegetables. Decrease intake of refined foods, } \\
\text { sugars, fats, and red meats in the meals. For } \\
\text { those above } 40 \text { years of age, consuming less salt } \\
\text { in the diet may help prevent kidney stones } \\
\text { (Shavit etal., 2015). }\end{array}$ \\
\hline $\begin{array}{l}\text { Physical } \\
\text { exercise/ } \\
\text { activity }\end{array}$ & $\begin{array}{l}\text { At least } 30 \text { minutes of regular aerobic exercise } \\
\text { (swimming, running, cycling, or fast walking) } \\
\text { maintains normal blood pressure, helps control } \\
\text { blood sugar, and reduces the risk of developing } \\
\text { kidney stones (Pickard et al., 2015). }\end{array}$ \\
\hline $\begin{array}{l}\text { Maintain a } \\
\text { bodyweight }\end{array}$ & $\begin{array}{l}\text { Maintain a healthy or balanced body weight } \\
\text { with a proper diet, burn calories, and regular } \\
\text { physical activity plans to achieve and stay at a } \\
\text { healthy weight (Roudakova \& Monga, 2014). }\end{array}$ \\
\hline $\begin{array}{l}\text { Stop smoking } \\
\text { or use tobacco } \\
\text { products and } \\
\text { manage } \\
\text { alcohol intake }\end{array}$ & $\begin{array}{l}\text { Smoking or use other tobacco products and } \\
\text { excessive intake amounts of alcohol increase } \\
\text { the risk of cardiovascular diseases (increase } \\
\text { blood pressure, cholesterol levels, and heart } \\
\text { attacks or strokes), which is associated with a } \\
\text { reduction of higher risk of these severe } \\
\text { conditions (Pearle et al., 2014). }\end{array}$ \\
\hline $\begin{array}{l}\text { Stop } \\
\text { overuse } \\
\text { NSAIDs }\end{array}$ & $\begin{array}{l}\text { Do not overuse NSAIDs (Ibuprofen, Aspirin, } \\
\text { Naproxen, etc.) regularly. NSAIDs are known } \\
\text { to cause kidney damage and subsequent } \\
\text { failure, particularly if taken regularly. Consult a } \\
\text { nephrologist to find the best way to control the } \\
\text { pain without damaging the kidneys (Scales et } \\
\text { al., 2016). }\end{array}$ \\
\hline
\end{tabular}

\section{CONCLUSION}

Nephrolithiasis and Urolithiasis are among the most widely recognized problems which influence the urinary system in developing countries like the United States, India, Italy, Germany, Scotland, Spain, Sweden, Japan, and the remainder of the world. Herbal drugs are used for centuries due to its safety, efficacy, cultural acceptability, and lesser adverse or side effects as compared to Allopathic drugs. The present review article deals with measures to be adopted for the potential of plants in the management (stone dissolving and expel activity) of kidney and urinary stones disease.

\section{ACKNOWLEDGMENT}

The authors are thankful for our deepest core of heart to Dr. Md. Iftekhar Ahmad for his valuable guidance.

\section{REFERENCES}

Abdel-Daim, M.M., Khalifa, H.A., Abushouk, A.I., DKhil, M.A., \& Al-Quraishy, S.A. (2017). Diosmin Attenuates Methotrexate-Induced Hepatic, Renal, and Cardiac Injury: A Biochemical and Histopathological Study in Mice. Oxidative Medicine and Cellular Longevity, 2017, 3281670. doi:10.1155/2017/3281670

Afsar, B., Kiremit, M.C., Sag, A.A., Tarim, K., Acar, O., Esen, T., Solak, Y., Covic, A., \& Kanbay, M. (2016). The role of sodium intake in nephrolithiasis: epidemiology, pathogenesis, and future directions. European Journal of Internal Medicine, 35, 16-19. doi:10.1016/j.ejim.2016.07.001

Ahmed, A.F., Gabr, A.H., Emara, A.A., Ali, M., AbdelAziz, A.S., \& Alshahrani, S. (2015). Factors predicting the spontaneous passage of a ureteric calculus of $\leqslant 10 \mathrm{~mm}$. Arab Journal of Urology, 13(2), 84-90. doi:10.1016/j.aju.2014.11.004

Albert, A., Tiwari, V., Paul, E., Ganesan, D., Ayyavu, M., Kujur, R., Ponnusamy, S., Shanmugam, K., Saso, L., \& Sadasivam, S.G. (2017). Expression of heterologous oxalate decarboxylase in HEK293 cells confers protection against oxalate induced oxidative stress as a therapeutic approach for calcium oxalate stone disease. Journal of Enzyme Inhibition and 
Medicinal Chemistry, 32(1), 426-433. doi:10.1080/14756366.2016.1256884

Arya, P., Pandey, S., \& Verma, V. (2017). Kidney stone formation and use of medicinal plants as antiurolithiatic agents. Universal Journal of Pharmaceutical Research, 2(4), 43-48. doi:10.22270/ujpr.v2i4.RW1

Aune, D., Mahamat-Saleh, Y., Norat, T., \& Riboli, E. (2018). Body fatness, diabetes, physical activity and risk of kidney stones: a systematic review and meta-analysis of cohort studies. European Journal of Epidemiology, 33(11), 1033-1047. doi:10.1007/s10654-018-0426-4

Aziz, F.M. \&Hassan, D.H. (2020). Radish Juice Promote Kidney Stone Deposition in Ethylene Glycolinduced Urolithiasis in Rats. Cihan UniversityErbil Scientific Journal, 4(1), 57-61. doi:10.24086/cuesj.v4n1y2020

Bultitude, M., Smith, D., \& Thomas, K. (2016). Contemporary Management of Stone Disease: The New EAU Urolithiasis Guidelines for 2015. European Urology, 69(3), 483-483. doi:10.1016/j.eururo.2015.08.010

Çakıroğlu, B., Eyyupoğlu, E., Hazar, A.I., Uyanik, B.S., \& Nuhoğlu, B. (2016). Metabolic assessment of recurrent and first renal calcium oxalate stone formers. Archivio Italiano di Urologia e Andrologia, $\quad$ 88(2), 101-105. doi:10.4081/aiua.2016.2.101

Chaveau, P., Aparicio, M., Belizzi, V., Campbell, K., Hong, X., Johansson, L., Kolko, A., Molina, P., Sezer, S., Wanner, C., Ter Wee, P.M., Teta, D., Fouque, D., Carrero, J.J., \& European Renal Nutrition (ERN) Working Group of the European Renal Association-European Dialysis Transplant Association (ERA-EDTA). (2018). Mediterranean diet as the diet of choice for patients with chronic kidney disease. Nephrology Dialysis Transplantation, 33(5), 723735. doi:10.1093/ndt/gfx085

Chen, K., Chen, D., Lan, C., Liang, X., Zeng, T., Huang, J., Duan, X., Kong, Z., Li, S., Tiselius, H.G., Gurioli, A., Lu, X., Zeng, G., \& Wu, W. (2018). Does green tea consumption increase urinary oxalate excretion? Results of a prospective trial in healthy men. International Urology and Nephrology, 50, 29-33. doi:10.1007/s11255-017$1720-x$
Cloutier, J., Villa, L., Traxer, O., \& Daudon, M. (2015). Kidney stone analysis: "Give me your stone, I will tell you who you are!". World Journal of Urology, 33(2), 157-169. doi:10.1007/s00345014-1444-9

Coe, F.L., Worcester, E.M. \& Evan, A.P. (2016). Idiopathic hypercalciuria and formation of calcium renal stones. Nature Reviews Nephrology, 12(9), 519533. doi:10.1038/nrneph.2016.101

Courbebaisse, M., Prot-Bertoye, C., Bertocchio, J.P., Baron, S., Maruani, G., Briand, S., Daudon, M., \& Houillier, P. (2017). [Nephrolithiasis of adult: From mechanisms to preventive medical treatment]. Revue Medicale Internationale, 38(1), 44-52. doi:10.1016/j.revmed.2016.05.013

Das, M. \& Malipeddi, H. (2016). Antiurolithiatic activity of ethanol leaf extract of Ipomoea eriocarpa against ethylene glycol-induced urolithiasis in male Wistar rats. Indian Journal of Pharmacology, 48(3), 270-274. doi:10.4103/0253-7613.182886

Daudon, M., Frochot, V., Bazin, D., \& Jungers, P. (2018). Drug-Induced Kidney Stones and Crystalline Nephropathy: Pathophysiology, Prevention and Treatment. Drugs, 78(2), 163-201. doi:10.1007/s40265-017-0853-7

Duan, X., Zhang, T., Ou, L., Kong, Z., Wu, W., \& Zeng, G. (2020). 1 H NMR-based metabolomic study of metabolic profiling for the urine of kidney stone patients. Urolithiasis, 48(1), 27-35. doi:10.1007/s00240-019-01132-2

Evan, A.P., Worcester, E.M., Coe, F.L., Williams, J., \& Lingeman, J.E. (2015). Mechanisms of human kidney stone formation. Urolithiasis, 43 Suppl 1(01), 19-32. doi:10.1007/s00240-014-0701-0

Ferraro, P.M., Marano, R., Primiano, A., Gervasoni, J., Bargagli, M., Rovere, G., Bassi, \& Gambaro, G. (2019). Stone composition and vascular calcifications in patients with nephrolithiasis. Journal of Nephrology, 32(4), 589-594. doi:10.1007/s40620-019-00619-w

Ferraro, P.M., Curhan, G.C., D’Addessi, A., \& Gambaro, G. (2017). Risk of recurrence of idiopathic calcium kidney stones: analysis of data from the literature. Journal of Nephrology, 30(2), 227233. doi:10.1007/s40620-016-0283-8

Fisang, C., Anding, R., Müller, S.C., Latz, S., \& Laube, N. (2015). Urolithiasis-an interdisciplinary 
diagnostic, therapeutic and secondary preventive challenge. Deutsches Ärzteblatt International, 112(6), 83-91. doi:10.3238/arztebl.2015.0083

Gambaro, G., Croppi, E., Bushinsky, D., Jaeger, P., Cupisti, A., Ticinesi, A., Mazzaferro, S., D'Addessi, A., \& Ferraro, P.M. (2017). The Risk of Chronic Kidney Disease Associated with Urolithiasis and its Urological Treatments: A Review. Journal of Urology, 198(2), 268-273. doi:10.1016/j.juro.2016.12.135

Gambaro, G., Croppi, E., Coe, F., Lingeman, J., Moe, O., Worcester, E., Buchholz, N., Bushinsky, D., Curhan, G.C., Ferraro, P.M., Fuster, D., Goldfarb, D.S., Heilberg, I.P., Hess, B., Lieske, J., Marangella, M., Milliner, D., Preminger, G.M., Santos J.M.R., Sakhaee, K., Sarica, K., Siener, R., Strazzullo, P., Williams, J.C., \& Consensus Conference Group. (2016). Metabolic diagnosis and medical prevention of calcium nephrolithiasis and its systemic manifestations: a consensus statement. Journal of Urology, 29(6), 715-734. doi:10.1007/s40620016-0329-y

Giardina, S., Scilironi, C., Michelotti, A., Samuele, A., Borella, F., Daglia, M., \& Marzatico, F. (2014). In vitro anti-inflammatory activity of selected oxalate-degrading probiotic bacteria: potential applications in the prevention and treatment of hyperoxaluria. Journal of Food Science, 79(3), M384-390. doi:10.1111/1750-3841.12344

Green, W. \& Ratan, H. (2013). Molecular mechanisms of urolithiasis. Urology, 81(4), 701-704. doi:10.1016/j.urology.2012.12.039

Han, H., Segal, A.M., Seifter, J.L., \& Dwyer, J.T. (2015). Nutritional Management of Kidney Stones (Nephrolithiasis). Clinical Nutrition Research, 4(3), 137-152. doi:10.7762/cnr.2015.4.3.137

Hollingsworth, J.M., Canales, B.K., Rogers, M.A.M., Sukumar, S., Yan, P., Kuntz, G.M., \& Dahm, P. (2016). Alpha blockers for treatment of ureteric stones: systematic review and meta-analysis. BMJ, 355, i6112. doi:10.1136/bmj.i6112

Holmes, R.P., Knight, J., \& Assimos, D.G. (2016). Lowering urinary oxalate excretion to decrease calcium oxalate stone disease. Urolithiasis, 44(1), 27-32. doi:10.1007/s00240-015-0839-4
Jung, H. \& Osther, P.J.S. (2015). Acute management of stones: When to treat or not to treat? World Journal of Urology, 33, 203-211. doi:10.1007/s00345-014-1353-y

Kanlaya, R., Singhto, N., \& Thongboonkerd, V. (2016). EGCG decreases binding of calcium oxalate monohydrate crystals onto renal tubular cells via decreased surface expression of alphaenolase. Journal of Biological Inorganic Chemistry, 21(3), 339-346. doi:10.1007/s00775-016-1344-0

Kapoor, D., Vyas, R.B., \& Dadarwal, D. (2017). Nephrolithiasis - an updated review in relation to diagnosis, prevention and treatment. Journal of Translational Medicine and Research, 1(2), 37-42. doi:10.15406/oajtmr.2017.01.00009

Khan, S.R., Pearle, M.S., Robertson, W.G., Gambaro, G., Canales, B.K., Doizi, S., Traxer, O., \& Tiselius, H.G. (2016). Kidney stones. Nature Reviews Disease Primers, 2, 16008. doi:10.1038/nrdp.2016.8

Kummer, A.E., Grams, M., Lutsey, P., Chen, Y., Matsushita, K., Kottgen, A., Folsom, A.R., \& Coresh, J. (2015). Nephrolithiasis as a Risk Factor for CKD: The Atherosclerosis Risk in Communities Study. Clinical Journal of the American Society of Nephrology, 10(11), 20232029. doi:10.2215/CJN.10111014

McTavish, R.K., Richard, L., McArthur, E., Shariff, S.Z., Acedillo, R., Parikh, C.R., Wald, R., Wilk, P., \& Garg, A.X. (2018). Association Between High Environmental Heat and Risk of Acute Kidney Injury Among Older Adults in a Northern Climate: A Matched Case-Control Study. American Journal of Kidney Diseases, 71(2), 200208. doi:10.1053/j.ajkd.2017.07.011

Nirumand, M.C., Hajialyani, M., Rahimi, R., Farzaei, Zingue, S., Nabavi, S.M., \& Bishayee, A. (2018). Dietary Plants for the Prevention and Management of Kidney Stones: Preclinical and Clinical Evidence and Molecular Mechanisms. International Journal of Molecular Sciences, 19(3), 765. doi:10.3390/ijms19030765

Pathan, S.A., Mitra, B., \& Cameron, P.A. (2018). A Systematic Review and Meta-analysis Comparing the Efficacy of Nonsteroidal Antiinflammatory Drugs, Opioids, and Paracetamol in the Treatment of Acute Renal 
Colic. European Urology, 73(4), 583-595. doi:10.1016/j.eururo.2017.11.001

Pearle, M.S., Goldfarb, D.S., Assimos, D.G., Curhan, G., Denu-Ciocca, C.J., Matlaga, B.R., Monga, M., Penniston, K.L., Preminger, G.M., Turk, T.M.T., White, J.R., \& American Urological Association. (2014). Medical management of kidney stones: AUA guideline. Journal of Urology, 192(2), 316-324. doi:10.1016/j.juro.2014.05.006

Pickard, R., Starr, K., MacLennan, G., Lam, T., Thomas, R., Burr, J., McPherson, G., McDonald, A., Anson, K., N’Dow, J., Burgess, N., Clark, T., Kilonzo, M., Gillies, K., Shearer, K., Boachie, C., Cameron, S., Norrie, J., \& McClinton, S. (2015). Medical expulsive therapy in adults with ureteric colic: a multicentre, randomised, placebo-controlled trial. The Lancet, 386(9991), 341-349. doi:10.1016/S0140-6736(15)60933-3

Podzik, A., Maalouf, N., Letavernier, E., Brocheriou, I., Body, J.J., Vervaet, B., Haute, C.V., Noels, J., Gadisseur, R., Castiglione, V., Cotton, F., Gambaro, G., Daudon, M., \& Sakhaee, K. (2019). Meeting report of the "Symposium on kidney stones and mineral metabolism: calcium kidney stones in 2017". Journal of Nephrology, 32(5), 681-698. doi:10.1007/s40620019-00587-1

Prabhu, V.V., Sathyamurthy, D., Ramasamy, A., Das, S., Anuradha, M., \& Pachiappan, S. (2016). Evaluation of protective effects of diosmin (a citrus flavonoid) in chemical-induced urolithiasis in experimental rats. Pharmaceutical Biology, 54(9), 1513-1521. doi:10.3109/13880209.2015.1107105

Prezioso, D., Strazzullo, P., Lotti, T., Bianchi, G., Borghi, L., Caione, P., Carini, M., Caudarella, R., Ferraro, M., Gambaro, G., Gelosa, M., Guttilla, A., Illiano, E., Martino, M., Meschi, T., Messa, P., Miano, R., Napodano, G., Nouvenne, A., Rendina, D., Rocco, F., Rosa, M., Sanseverino, R., Salerno, A., Spatafora, S., Tasca, A., Ticinesi, A., Travaglini, F., Trinchieri, A., Vespasiani, G., \& Zattoni, F. (2016). ERRATUM: Dietary treatment of urinary risk factors for renal stone formation. A review of CLU Working Group. Archivio Italiano di Urologia e Andrologia, 88(1), 76. doi:10.4081/aiua.2016.1.76

Primarizky, H., Yuniari, W.M., \& Lukiswanto, B.S. (2016). Benefits of pomegranate (Punica granatum
Linn) fruit extracts to weight changes, total protein, and uric acid in white rats (Rattus norvegicus) as an animal model of acute renal failure. Veterinary World, 9(11), 1269-1274. doi:10.14202/vetworld.2016.1269-1274

Ragettli, M.S., Vicedo-Cabrera, A.M., Schindler, C., \& Röösli, M. (2017). Exploring the association between heat and mortality in Switzerland between 1995 and 2013. Environmental Research, 158, 703-709. doi:10.1016/j.envres.2017.07.021

Rodger, F., Roditi, G., \& Aboumarzouk, O.M. (2018). Diagnostic Accuracy of Low and Ultra-Low Dose CT for Identification of Urinary Tract Stones: A Systematic Review. Urologia Internationalis, $\quad 100(4), \quad 375-385$. doi:10.1159/000488062

Rodgers, A., Mokoena, M., Durbach, I., Lazarus, J., de Jager, S., Ackermann, H., Breytenbach, I., Okada, A., Usami, M., Hirose, Y., Ando, R., Yasui, T., \& Kohri, K. (2016). Do teas rich in antioxidants reduce the physicochemical and peroxidative risk factors for calcium oxalate nephrolithiasis in humans? Pilot studies with Rooibos herbal tea and Japanese green tea. Urolithiasis, 44(4), 299-310. doi:10.1007/s00240015-0855-4

Ross, M.E., Vicedo-Cabrera, A.M., Kopp, R.E., Song, L., Goldfarb, D.S., Pulido, J., Warner, S., Furth, S.L., \& Tasian, G.E. (2018). Assessment of the combination of temperature and relative humidity on kidney stone presentations. Environmental Research, 162, 97-105. doi:10.1016/j.envres.2017.12.020

Roudakova, K. \& Monga, M. (2014). The evolving epidemiology of stone disease. Indian Journal of Urology, 30(1), 44-48. doi:10.4103/09701591.124206

Scales, C.D., Tasian, G.E., Schwaderer, A.L., Goldfarb, D.S., Star, R.A., \& Kirkali, Z. (2016). Urinary Stone Disease: Advancing Knowledge, Patient Care, and Population Health. Clinical Journal of the American Society of Nephrology, 11(7), 13051312. doi:10.2215/cjn.13251215

Shang, W., Li, Y., Ren, Y., Yang, Y., Li, H., \& Dong, J. (2017). Nephrolithiasis and risk of hypertension: a meta-analysis of observational studies. BMC Nephrology, 18, 344. doi:10.1186/s12882-017-0762-8 
Sharifiyan, F., Movahedian-Attar, A., Nili, N., \& Asgary, S. (2016). Study of pomegranate (Punica granatum L.) peel extract containing anthocyanins on fatty streak formation in the renal arteries in hypercholesterolemic rabbits. Advanced Biomedical Research, 5, 8. doi:10.4103/2277-9175.175241

Shavit, L., Ferraro, P.M., Johri, N., Robertson, W., Walsh, S.B., Moochhala, S., \& Unwin, R. (2015). Effect of being overweight on urinary metabolic risk factors for kidney stone formation. Nephrology Dialysis Transplantation, 30(4), 607-613. doi:10.1093/ndt/gfu350

Skolarikos, A., Straub, M., Knoll, T., Sarica, K., Seitz, C., Petř́k, A., \& Türk, C. (2015). Metabolic evaluation and recurrence prevention for urinary stone patients: EAU guidelines. European Urology, 67(4), 750-763. doi:10.1016/j.eururo.2014.10.029

Smith-Bindman, R., Aubin, C., Bailitz, J., Bengiamin, R.N., Camargo, C.A., Corbo, J., Dean, A.J., Goldstein, R.B., Griffey, R.T., Jay, G.D., Kang, T.L., Kriesel, D.R., Ma, O.J., Mallin, M., Manson, W. Melnikow, J., Miglioretti, D.L., Miller, S.K., Mills, L.D., Miner, J.R., Moghadassi, M. Noble, V.E., Press, G.M., Stoller, M.L., Valencia, V.E., Wang, J., Wang, R.C., \& Cummings, S.R. (2014). Ultrasonography versus Computed Tomography for Suspected Nephrolithiasis. The New England Journal of Medicine, 371(12), 1100-1110. doi:10.1056/NEJMoa1404446

Spatola, L., Ferraro, P.M., Gambaro, G., Badalamenti, S., \& Dauriz, M. (2018). Metabolic syndrome and uric acid nephrolithiasis: insulin resistance in focus. Metabolism: Clinical and Experimental, 83, 225-233. doi:10.1016/j.metabol.2018.02.008

Strepper, N.M. (2018). Asymptomatic Renal Stones-to Treat or Not to Treat. Current Urology Reports, 19(5), 29. doi:10.1007/s11934-018-0782-3

Tavasoli, S., Alebouyeh, M., Naji, M., Majd, G.S., Nashtaei, M.S., Broudmandnia, N., \& Basiri, A. (2020). Association of intestinal oxalatedegrading bacteria with recurrent calcium kidney stone formation and hyperoxaluria: a case-control study. BЛU International, 125(1), 133-143. doi:10.1111/bju.14840

Ticinesi, A., Nouvenne, A., \& Meschi, T. (2019). Gut microbiome and kidney stone disease: not just an Oxalobacter story. Kidney International, 96(1), 25-27. doi:10.1016/j.kint.2019.03.020

Ticinesi, A., Guerra, A., Allegri, F., Nouvenne, A., Cervellin, G., Maggio, M., Lauretani, F., Borghi, L., \& Meschi, T. (2018). Determinants of calcium and oxalate excretion in subjects with calcium nephrolithiasis: the role of metabolic syndrome traits. Journal of Nephrology, 31, 395403. doi:10.1007/s40620-017-0453-3

Türk, C., Petřík, A., Sarica, K., Seitz, C., Skolarikos, A., Straub, M., \& Knoll, T. (2016). EAU Guidelines on Diagnosis and Conservative Management of Urolithiasis. European Urology, 69(3), 468-474. doi:10.1016/j.eururo.2015.07.040

Unno, R., Kawabata, T., Taguchi, K., Sugino, T., Hamamoto, S., Ando, R., Okada, A., Kohri, K., Yoshimori, T., \& Yasui, T. (2020). Deregulated MTOR (mechanistic target of rapamycin kinase) is responsible for autophagy defects exacerbating kidney stone development. Autophagy, 16(4), 709-723. doi:10.1080/15548627.2019.1635382

Vicedo-Cabrera, A.M., Goldfarb, D.S., Kopp, R.E., Song, L., \& Tasian, G.E. (2020). Sex differences in the temperature dependence of kidney stone presentations: a population-based aggregated case-crossover study. Urolithiasis, 48(1), 37-46. doi:10.1007/s00240-019-01129-x

Wang, H., Man, L.B., Huang, G.L., Li, G.Z., \& Wang, J.W. (2016). Comparative efficacy of tamsulosin versus nifedipine for distal ureteral calculi: a meta-analysis. Drug Design, Development, and Therapy, 10, 1257-1265. doi:10.2147/DDDT.S99330

Wijarnpreecha, K., Lou, S., Panjawatanan, P., Sanguankeo, A., Pungpapong, S., Lukens, F.J., \& Ungprasert, P. (2018). Nonalcoholic Fatty Liver Disease and Urolithiasis. A Systematic Review and Meta-Analysis. Journal of Gastrointestinal and Liver Diseases, 27(4), 427432. doi:10.15403/jgld.2014.1121.274.nac

Yiu, A.J., Callaghan, D., Sultana, R., \& Bandyopadhyay, B.C. (2015). Vascular Calcification and Stone Disease: A New Look towards the Mechanism. Journal of Cardiovascular Development and Disease, 2(3), 141-164. doi:10.3390/jcdd2030141 
Zhu, W., Xu, Y.F., Feng, Y., Peng, B., Che, J.P., Liu, M., \& Zheng, J.H. (2014). Prophylactic effects of quercetin and hyperoside in a calcium oxalate stone forming rat model. Urolithiasis, 42(6), 519-

526. doi:10.1007/s00240-014-0695-7 